Approved for public release; distribution is unlimited.

Title:

MICRO FUEL CELI
CONF-981108--

Author(s):

Submitted to:

ELECTROCHEMICAL SOCIETY

Boston, MA

$11 / 2-6 / 1998$

L. A. ZOOK

N. E. VANDERBORGH

R. HOCKADAY
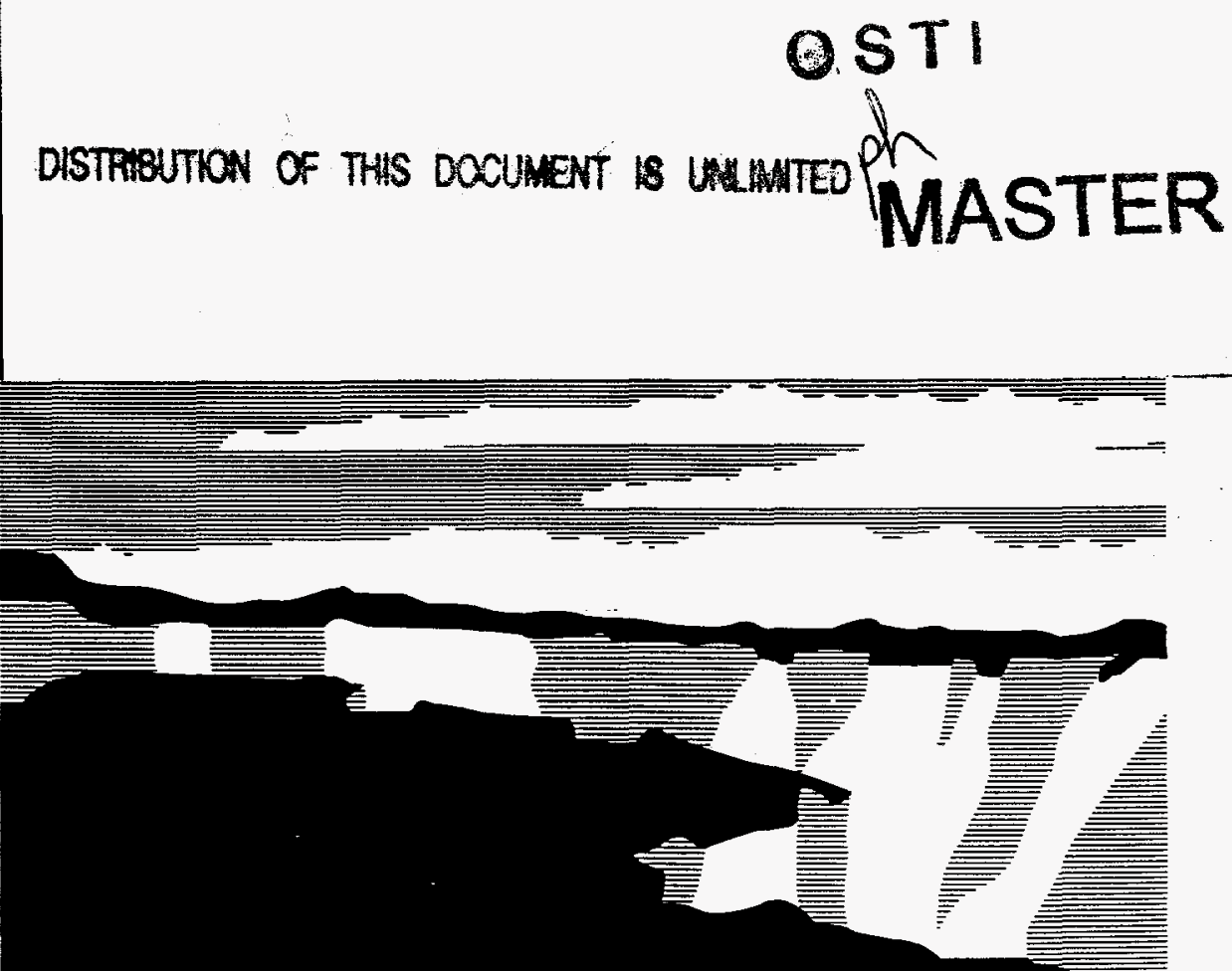

NATIONAL LABORATORY

Los Alamos National Laboratory, an affirmative actionequal opportunity employer, is operated by the University of Califomia for the U.S. Department of Energy under contract W-7405-ENG-36. By acceptance of this article, the publisher recognizes that the U.S. Govemment retains a nonexclusive, royalty-free license to publish or reproduce the published form of this contribution, or to allow others to do so, for U.S. Govemment purposes. Los Alamos National Laboratory requests that the publisher identify this article as work performed under the auspices of the U.S. Department of Energy. The Los Alamos National Laboratory strongly supports academic freedom and a researcher's right to publish; as an institution, however, the Laboratory does not endorse the viewpoint of a putblication or guarantee its technical correctness. 


\section{DISCLAMMER}

This report was prepared as an account of work sponsored by an agency of the United States Government. Neither the United States Government nor any agency thereof, nor any of their employees, makes any warranty, express or implied, or assumes any legal liability or responsibility for the aceuracy, completeness, or usefulbess of any information, apparatus, product, or process disclosed, of represents that its use would not infringe privately owned rights. Reference herein to any specific commercial product. process, or service by trade aame, trademart, inanufacturer, or otherwise does not necesearily constitute or imply its endorsement, recommendation, or favoring by the United States Government or any agency thereof. The views and opinions of authors expressed herein do not atecessarily state or reflect those of the United States Govermmeat or any agency thereof. 


\section{DISCLAIMER}

Portions of this document may be illegible in electronic image products. Images are produced from the best available original document. 


\title{
MICRO FUEL CELL
}

\author{
${ }^{\dagger}$ Lois Anne Zook, ${ }^{\ddagger}$ Robert Hockaday, and ${ }^{\dagger}$ Nicholas E. Vanderborgh \\ ${ }^{\dagger}$ Los Alamos National Laboratory \\ Engineering Science Applications-Energy and Process Engineering \\ MS J576, Los Alamos, NM 87545 \\ ${ }^{\ddagger}$ Energy Related Devices Inc. \\ 127 Eastgate Industrial Park, Los Alamos, NM 87544
}

\begin{abstract}
An ambient temperature, liquid feed, direct methanol fuel cell device is under development. A metal barrier layer was used to block methanol crossover from the anode to the cathode side while still allowing for the transport of protons from the anode to the cathode.
\end{abstract}

\section{INTRODUCTION}

A direct methanol fuel cell (DMFC) is an electrochemical engine that converts chemical energy into clean electrical power by the direct oxidation of methanol at the fuel cell anode. This direct use of a liquid fuel eliminates the need for a reformer to convert the fuel to hydrogen before it is fed into the fuel cell. Energy Related Devices (ERD) is currently developing a class of portable power supplies, beginning in the $<5 \mathrm{~W}$ size range, suitable to power portable communications devices (i.e., cellular telephones). These fuel cells will operate on ambient air and a methanol/water solution as the fuel. Los Alamos National Laboratory, under the auspices of a Cooperative Research and Development Agreement (CRADA), aided ERD in product evolution of their micro fuel cell through component testing and evaluation of fuel cell devices.

A schematic for the micro fuel cell is given in figure 1. The methanol oxidation reaction at the anode (assuming no intermediate products) is given by:

$$
\mathrm{CH}_{3} \mathrm{OH}+\mathrm{H}_{2} \mathrm{O} \Rightarrow \mathrm{CO}_{2}+6 \mathrm{H}^{+}+6 \mathrm{e}^{-}
$$

At the cathode, the oxygen reduction reaction is given by: 


$$
3 / 2 \mathrm{O}_{2}+6 \mathrm{H}^{+}+6 \mathrm{e}^{-} \Rightarrow 3 \mathrm{H}_{2} \mathrm{O}
$$

This gives an overall cell reaction of:

$$
\mathrm{CH}_{3} \mathrm{OH}+3 / 2 \mathrm{O}_{2} \Rightarrow \mathrm{CO}_{2}+2 \mathrm{H}_{2} \mathrm{O}
$$

For the complete oxidation of methanol, six electrons and protons must be exchanged, resulting in inherently slower reaction kinetics than that for a hydrogen/oxygen fuel cell. ${ }^{1}$ Because it is highly unlikely that this process occurs simultaneously, intermediates are also formed during methanol oxidation. ${ }^{2}$ Effort has been directed at finding better anode catalysts to improve the reaction kinetics and drive the reaction more fully to completion. ${ }^{3}$ The reversible cell potential for reaction [3] is $1.214 \mathrm{~V} .{ }^{4}$ However, due to slow methanol oxidation kinetics, other losses at the anode and cathode, and ohmic losses due to internal resistance of the fuel cell, the output for a DMFC is much lower than $1.214 \mathrm{~V}$. Methanol can also cross over the ion exchange membrane separator, poisoning the cathode catalyst, further degrading fuel cell performance. ${ }^{5}$

Polymer electrolyte membrane separator materials are currently limited by the fuel crossover problem. This is due to the fact that membrane separator materials must allow for proton conduction from the anode to the cathode. Protons are typically solvated by water, and cross the membrane in the form of $\mathrm{H}_{3} \mathrm{O}^{+}$. Methanol is extremely miscible in water, and as such, membranes that allow $\mathrm{H}_{3} \mathrm{O}^{+}$to diffuse facilely from the anode to the cathode also allow methanol to crossover. Attempts to block methanol crossover invariably reduce proton conductivity as well, resulting in poorer performance, albeit due to increased resistance rather than cathode poisoning.

One method currently being used to reduce methanol crossover involves using a variety of polymer membranes other than Nafion. ${ }^{6,7}$ In contrast, the proprietary membranes reported here, manufactured by ERD and tested at LANL, incorporate a metal hydride layer as a barrier to methanol crossover. The proton no longer crosses the barrier in the form of $\mathrm{H}_{3} \mathrm{O}^{+}$, but rather the proton undergoes a reductive adsorption along the metal barrier layer on the anode side. $\mathrm{H}^{*}$ can then transport through the metal hydride to the surface of the metal barrier layer on the cathode side, where it is oxidatively desorbed as a proton. Smotkin and co-workers have reported on a similar system using a palladium foil barrier layer. ${ }^{8}$ However, in their system, the fuel stream included $\mathrm{H}_{2}$ as well as methanol and the operating temperature was $100^{\circ} \mathrm{C}$. Here, we report on a variety of metal barrier layers other than pure palladium foil, liquid fuel streams consisting solely of methanol and water at ambient temperature, and much thinner barrier layers that significantly reduce the cost of precious metal materials per cell. The thin barrier/catalyst 
layer is significant, as the cost of the noble-metal catalyst is still a major concern in fuel cell development. ${ }^{9}$

Several different substrate materials, ionomers, and barrier layer formulations were tested and compared to develop a reliable and cost-effective membrane separator. Fuel cell catalyst materials that are robust with sufficient electrochemically active surface areas have also been developed at ERD and tested at Los Alamos. These catalysts were characterized at LANL using both electrochemical and microscopic techniques to aid in the design of materials with optimal performance.

In addition to component testing, several functional fuel cell arrays have been fabricated and tested. These demo fuel cell arrays have been used to charge a battery to make cellular phone calls. These fuel cell arrays contain several cells connected in series, and can operate on hydrogen or a 1:1 methanol to water mixture.

Commercialization of the DMFC necessitates fuel cells that are economical compared to existing technologies, e.g., batteries. Over the course of the CRADA, ERD, in collaboration with LANL, has made significant progress in the fabrication of cost effective membranes and catalyst materials for small, low power electricity producing hardware suitable to cellular telephones. ERD expects to produce several prototype devices within the next six months.

\section{EXPERIMENTAL}

\section{Characterization of Fuel Cell Component Materials}

Membrane optimization included testing different polymer substrate materials, developing irradiation, etching, and/or ion milling procedures to sculpt the substrate surface appropriately, testing different ionomers and ionomer loadings, coating the membrane with different methanol blocking barrier layer formulations, and developing high surface area catalysts. A variety of testing procedures were used to identify ideal materials for membrane manufacture and assembly.

Spectroscopic techniques were used to examine many stages of manufacture of the fuel cell components. Microscopy techniques can be used to determine the structure, morphology, and composition of fuel cell components. ${ }^{10}$ Scanning electron microscopy (SEM) was used to evaluate and characterize the substrate materials, the ionomer materials, the barrier layers, and the catalyst formulations. Electron micrographs were used to look at the surface structure of catalyst films and barrier layers both before and after the materials were used in experimental studies. 
Diffusion measurements to determine crossover rates for both methanol and hydrogen were performed. Crossover was measured by chromatography and by differential pressure measurements.

An electrochemical method based on the coulometry of hydrogen adsorption and desorption was used to measure the electrochemically active surface areas of the catalyst deposits. The surface area of the vacuum deposited catalyst layers was measured by integrating the adsorbed hydrogen oxidation peak of a cyclic voltammogram taken at 5 $\mathrm{mV} / \mathrm{s}$, using the conversion factor that for hydrogen at monolayer coverage on platinum, the charge density is $210 \mu \mathrm{C} / \mathrm{cm}^{2}$ platinum surface area. Electrochemical surface area determinations used to evaluate the catalyst deposits helped in the identification of deposition methods leading to catalysts with the highest electrochemical activity. The electrochemical measurements were used in conjunction with crossover measurements and the spectroscopic data to identify membrane manufacturing techniques which lead to mechanically robust and catalytically active fuel cell assemblies.

Substrate Materials: Scanning electron microscopy was used to examine the effectiveness of a variety of surface roughening procedures used to increase adhesion between the polymer substrate materials and the metal deposits. A JEOL JSM-6300FXV scanning electron microscope with $15 \AA$ resolution was used to examine the substrates. Substrate materials studied included polypropylene, polyimide, and polycarbonate.

Polypropylene and polyimide were irradiated and etched with californium 252 fission fragments to produce particle tracks. Electron microscopy was used to confirm the etched particle tracks. The polyimide samples revealed shallow pit track etches while the polypropylene showed well resolved particle track cones.

Fission fragment irradiated and etched polycarbonate membranes were also examined. See figure 2. Oxygen ion milling of the polycarbonate substrate created sub micron sculpting of the polymer surface. This surface roughening increases the adherence of the metal barrier layers to the substrate, significantly reducing the problem of de-lamination. Ion milled polycarbonate was determined to be a suitable material for the fuel cell substrate, and was the substrate used in subsequent experiments, unless otherwise noted.

Ionomer Optimization: Two different ion exchange polymers were studied. Diffusion of hydrogen and methanol through polycarbonate membranes coated with varying ionomer and metal barrier layers was measured. Nafion ${ }^{\top M}$, a DuPont ionomer, was compared to a partially sulfonated styrene-ethylene/butylene-styrene triblock polymer. 
Diffusion measurements were performed by placing membranes coated with different metal barrier layers into a sample holder, and passing methanol or hydrogen on one side of the sample. A carrier gas, e.g., argon, is passed on the opposite side of the membrane and delivered to a gas chromatograph (GC). Any methanol or hydrogen that crosses over the membrane is swept out of the sample holder in the argon gas stream and is quantified using the GC. The Shimadzu GC-8A gas chromatograph used for these experiments had a $1 \mathrm{ml}$ sample loop, so methanol crossover is reported in $\mu \mathrm{g}$ of methanol per $1 \mathrm{ml}$ sample.

Nafion coated polycarbonate membranes had methanol crossover of $19.73 \mu \mathrm{g} / \mathrm{ml}$. A polycarbonate membrane coated with the same polymer loading of a more economical, proprietary polymer had a methanol crossover of $16.15 \mu \mathrm{g} / \mathrm{ml}$. Membranes with the same polycarbonate substrate and metal barrier layer coating, but with varying ionomer loading of $0.03 \mathrm{ml}$ and $0.05 \mathrm{ml}$ of the proprietary polymer, had very similar methanol crossover rates $(<10 \%$ difference in crossover at almost double the ionomer loading). In other words, increasing the ionomer loading from $0.03 \mathrm{ml}$ to $0.05 \mathrm{ml}$ does little to decrease crossover. The low ionomer loading levels combined with the use of the less expensive proprietary polymer decreases the cost of membrane manufacture, yielding more cost effective fuel cells.

Metal Barrier Layers and Catalysts: Metal barrier layers that reduce methanol crossover were fabricated using several different vacuum deposition techniques. Composite films containing more than one type of metal were also examined. Pure palladium coatings were found to crack under $0.75 \mathrm{~atm}$. hydrogen hydration. Composite films of platinum and palladium on a polycarbonate substrate showed no apparent cracking. Effective methanol barrier layers depend on high membrane integrity. As one would predict, the uncracked composite films had the least amount of measured methanol crossover.

Crossover rates were measured by both $\mathrm{GC}$ and a differential pressure method. In the differential pressure method, the change in pressure across a membrane is monitored as a function of time to determine how much methanol is diffusing through the film. Results from these experiments were in close agreement with the chromatography method.

Electrode catalyst layers are sputtered as thin films onto the barrier layer. High porosity catalysts have been vacuum deposited with both good adhesion to the membranes and high active surface areas. High pressure sputtered platinum deposited on the barrier film showed high performance in fuel cell tests.

Surface area measurements were taken for several different catalyst formulations. Electrochemical measurements of the active catalyst area was determined using the cyclic voltammetric method reported by Tran and Langer. ${ }^{11}$ A three electrode cell was 
employed, with the membrane of interest as the working electrode, a platinum mesh counter electrode, and a saturated calomel reference electrode. An Electrosynthesis Co. Inc. Cat.\# C-600 Membrane Cell was used for these experiments. The electrolyte used was $0.5 \mathrm{M} \mathrm{H}_{2} \mathrm{SO}_{4}$. The solution was degassed with $\mathrm{N}_{2}$ for 15 minutes before experiments were run. During this period, the electrode was held at $200 \mathrm{mV}$ versus the saturated calomel electrode. This was followed by a preactivation step at the working electrode involving scanning the potential between $1000 \mathrm{mV}$ and $-250 \mathrm{mV}$ at a scan rate of $85 \mathrm{mV} / \mathrm{s}$ for approximately 15 minutes. The actual voltammogram for measuring the surface area of the membrane was obtained at $5 \mathrm{mV} / \mathrm{s}$. The initial potential was $200 \mathrm{mV}$, the potential was swept to $1000 \mathrm{mV}$, then back to $-250 \mathrm{mV}$, and back to a final potential of $400 \mathrm{mV}$. An example of the resulting cyclic voltammogram is shown in figure 3. Figure 4 is the same data plotted versus time, with the hydrogen desorption peak shaded in gray. A Pine bipotentiostat model AFCBP1 using PineChem 2.0 software was used to take to take the data. The software program integrated the hydrogen desorption region. This integrated charge was used to calculate the active surface area using the assumptions that there was monolayer hydrogen atom coverage and that hydrogen has a charge density of 210 $\mu \mathrm{C} / \mathrm{cm}^{2}$ of platinum surface. ${ }^{11}$

Each surface area experiment was run in triplicate, and the results averaged with the standard deviation reported. Several samples were taken from various areas of a single large membrane for each given catalyst formulation. Samples taken from the center of the larger membrane consistently had the highest surface areas, while samples from the corners and sides had lower surface areas, regardless of the membrane measured. The sample holder for the membrane was $2.5 \mathrm{~cm}^{2}$. Because the catalysts were porous, the electrochemically active surface areas were much higher than $2.5 \mathrm{~cm}^{2}$, and varied from $\sim 15-280 \mathrm{~cm}^{2}$. Standard deviations for measurements made on the same piece of membrane were in the range of $2-5 \%$, while standard deviations for different pieces of membrane taken from the same larger sputter coated sheet were on the order of 100$200 \%$. This suggests the need for significant improvements in the production of more uniform coatings. The ideal membrane would have a high electrochemical surface area, maintain mechanical integrity upon repeated cycling, and could be manufactured reproducibly.

\section{Device Optimization}

Single Cell Fuel Cell Testing: Membrane electrode assemblies (MEAs) incorporating barrier layers were examined. These MEAs were placed in an ElectroChem $25 \mathrm{~cm}^{2}$ fuel cell test hardware. Compressed air flowed through the cell from a gas cylinder. The initial gas cylinder regulators were used to reduce the gas pressure to $20 \mathrm{psi}$. A needle nose valve was used to adjust the flow through the flow meter to $280 \mathrm{cc} / \mathrm{min}$. A pressure gauge was set at the fuel cell outlet to 4 psi back pressure using a second needle 
nose valve to maintain the internal pressure in the fuel cell at 4 psi. A Fisher Scientific Acuflow Series II HPLC pump was used to flow the methanol/water mixtures through the fuel cell. See figure 5 for the test apparatus set-up. The pump was set at $9 \mathrm{ml} / \mathrm{min}$ flow rate for all experiments. Methanol solutions were filtered with a 0.5 micron filter and degassed by sparging the methanol solutions with $\mathrm{He}$ for 15 minutes prior to use in the HPLC pump. Helium is sparingly soluble in methanol and water, and dissolved atmospheric gases such as $\mathrm{N}_{2}$ and $\mathrm{O}_{2}$ diffuse into the helium bubbles and are swept from the system.

Air and methanol solution flow rates were set and the cell was allowed to equilibrate for 10-15 minutes before data were taken. The open circuit voltage was recorded. A series of resistors ranging from $2 \mathrm{k} \Omega$ to $2 \Omega$ were used as the load. The voltage was allowed to stabilize for several minutes between each load change before data were recorded. Methanol concentrations used included $1 \mathrm{M}, 3 \mathrm{M}$ and $8 \mathrm{M}$. These concentrations correspond to solutions containing approximately $5-20 \%$ methanol in water.

The MEAs tested were set up in the fuel cell assembly as shown in figure 6, with MEAs consisting of Nafion and catalyzed carbon electrodes on Nafion 117. Barrier layers were sandwiched between two electrodes pressed to Nafion membranes. Proton conduction was maintained by placing $1 \mathrm{ml}$ of $1 \mathrm{~N} \mathrm{H}_{2} \mathrm{SO}_{4}$ between each layer. The cell assembly was tightly clamped to maintain proper contact between each layer of the assembly.

MEAs used in initial tests were made in house from catalyst inks pressed to Nafion 117 membranes using the decal method. ${ }^{12}$ Electrodes were coated on both sides of the Nafion. In later tests, ELAT electrodes purchased from Etek Inc were used. For the anode side, ELAT $20 \% \mathrm{Pt} / \mathrm{Ru} / \mathrm{C} 1: 1 \mathrm{a} /$ o electrodes with $0.5 \mathrm{mg} / \mathrm{cm}^{2} \mathrm{Pt} / \mathrm{Ru}$ loading were used. The Pt:Ru catalyst was used because $\mathrm{Pt}-\mathrm{Ru} / \mathrm{C}$ catalyst has been found to be superior for the methanol oxidation reaction at ambient and elevated temperatures. ${ }^{13}$ Electrodes were $5 \times 5 \mathrm{~cm}$ and were heat pressed to a Nafion 117 membrane. Only one side of the Nafion film had an electrode on it. At the cathode, an ELAT $20 \% \mathrm{Pt} / \mathrm{C} 0.5 \mathrm{mg} / \mathrm{cm}^{2}$ loading $5 \times 5 \mathrm{~cm}$ electrode was used. Internal gasketing layers are not shown in figure 6 , but were located internal next to each current collector/flow field.

Eight different MEA sandwiches consisting of the ELAT electrodes and Nafion 117 polymer were examined. The combinations were as follows: an MEA with no internal barrier layer, an MEA with an uncoated $0.015 \mu \mathrm{m}$ diameter pore polycarbonate membrane as the internal barrier layer, an MEA with an uncoated $1.0 \mu \mathrm{m}$ diameter pore nucelopore polycarbonate membrane as the internal barrier layer, an MEA with a $0.025 \mathrm{~mm}$ thick Aldrich $25 \mathrm{~cm}^{2}$ palladium foil as the internal barrier layer, and four different ERD sputter coated thin metal films supported on nucleopore polycarbonate membranes. The ERD membrane formulations will be referred to by the designations 
ERD1, ERD2, ERD3, and ERD4 barrier layers. Each contained mixtures of transition metals such as platinum, palladium, etc. deposited onto the polycarbonate substrate under varying sputtering conditions. ERD films were on the order of $750 \AA$ thick.

Figure 7 shows the polarization curve for all $8 \mathrm{MEA}$ formulations using $1 \mathrm{M}$ methanol solution. At low current densities $(<5 \mathrm{~mA})$, ERD1 showed the best performance, followed by the $0.025 \mathrm{~mm}$ thick palladium foil, ERD2, ERD3, no internal membrane, ERD4, $0.015 \mu \mathrm{m}$ nucleopore polycarbonate membrane, and $1 \mu \mathrm{m}$ nucleopore polycarbonate membrane. At low current densities, little fuel is being utilized, and more methanol is available for crossover. For this reason, films that block methanol best (such as the palladium foil) have the best response.

At higher current density, the response is different. The MEA with no internal barrier layer works best, followed by the $0.015 \mu \mathrm{m}$ nucleopore polycarbonate membrane, the $1 \mu \mathrm{m}$ nucleopore polycarbonate membrane, ERD3, ERD4, ERD2, the $0.025 \mathrm{~mm}$ palladium foil, and ERD1. At these higher currents, resistance through the cell added by the internal barrier layers provides a higher penalty than any gains provided by reduction in methanol crossover.

Figures 8 and 9 show similar trends for the $3 \mathrm{M}$ and $8 \mathrm{M}$ methanol. Again, barrier layers improve performance at low current densities, but degrade performance through the addition of a resistant inner layer at higher current densities. One point to note, ERD3 performs almost as well as no internal barrier layer at high current densities. See figure 10. This suggests that if the resistance of the membrane can be decreased while maintaining the methanol blocking capability of the barrier layer, significant improvements can be made.

Gottesfeld recently reported that within the range of $0.5-1 \mathrm{M}$ methanol concentration, that fuel cell performance is independent of concentration. ${ }^{14}$ One possible explanation could be that increasing the water in the anode feed alters the product distributions of the methanol oxidation reaction, resulting in fewer intermediate products in the exhaust stream as the oxidation reaction goes more fully to completion. ${ }^{15}$ Water is thought to aid in the oxidation process by forming oxygen containing $\mathrm{OH}_{\text {ads }}$ species on the catalyst at low potentials. This does not necessarily explain Gottesfeld's data, since it's very possible that $1 \mathrm{M}$ methanol has sufficient water to aid in the oxidation reaction, but it is one possibility. In our case, as the methanol concentration increased from $1 \mathrm{M}$ to $8 \mathrm{M}$ as seen in figures 7-9, the current density decreased, although not as quickly for the cells with internal barrier layers. While most likely attributable to imperfections in the barrier layer that allow some methanol to still crossover, this decrease could also be due to the changing water/methanol mole ratio. This shift in the product distribution may be even more critical at ambient temperatures, as increasing the temperature of the DMFC also results in a more complete oxidation process. ${ }^{16}$ 
The present maximum power output obtained was $1 \mathrm{~mW} / \mathrm{cm}^{2}$ with air and $1 \mathrm{M}$ methanol. This is still quite low when compared to $220 \mathrm{~W} / \mathrm{cm}^{2}$ obtained by Hogarth et.al. for a vapor-feed system ${ }^{17}$ and $79 \mathrm{~W} / \mathrm{cm}^{2}$ for a liquid feed system. ${ }^{18}$ Ravikumar and Shukla reported a power density of $200 \mathrm{~W} / \mathrm{cm}^{2}$ for a liquid-feed methanol fuel cell system. ${ }^{19}$ Surampudi et.al. reported a power output of $150 \mathrm{~W} / \mathrm{cm}^{2}$ for a liquid feed system. ${ }^{20}$ In each of these cases, however, they were working at much higher temperatures, higher anode catalyst loading, and in some cases, with oxygen instead of air. Fuel concentrations also varied, so a direct comparison is not possible. At temperatures as high as $130^{\circ} \mathrm{C}$, Cleghorn et.al. reported performances of $0.6 \mathrm{~A} / \mathrm{cm}^{2}$ at $0.7 \mathrm{~V} .{ }^{21}$ In the case of a small, compact system such as that being proposed, the insulation requirements and thermal management issues involved with such a high temperature system add too much complexity to the cell. Minimum power outputs required for the micro fuel cell system are on the order of $1-10 \mathrm{~W} / \mathrm{cm}^{2}$ at ambient conditions, and are already attainable with the current technology. In fact, systems that produce more than $150 \mathrm{~W} / \mathrm{cm}^{2}$ would generate too much heat as they operate, and also would require more sophisticated methods of thermal management.

There is, however, room for substantial improvements to the current micro fuel cell design. New, thinner substrate materials with higher porosities are currently being fabricated. Barrier layer membranes with the cathode and anode sputtered directly onto either side will also have lower resistance than the MEA set-up discussed above, which consisted of carbon cloth electrodes and two layers of Nafion 117.

Micro Fuel Cell Arrays: To demonstrate the practical application of the micro fuel cell device, a hydrogen/air fuel cell array with three four-cell arrays (12 in series) was used to charge a 6-Volt lead battery and make cellular phone calls. This array consisted of a porous polycarbonate membrane soaked in ionomer coated with a thin barrier layer and sputtered catalyst layers for the anode and cathode. During the charging, the peak power output of the array was $47 \mathrm{~mW}$ at 6.5 Volts. Each of the four cell arrays could put out 3.03.2 Volts open circuit and $10 \mathrm{~mA}$ at 1 Volt.

A second micro fuel cell array operating on ambient air and fueled by a 1:1 methanol to water mixture achieved $1.7 \mathrm{~mW}$ at 4.36 Volts. Methanol can be delivered to the system by either by direct injection with a small syringe or by bubbling an inert gas through a mixture of methanol and water. The array consisted of 16 cells in series and was used to charge a lead acid battery in a portable phone. This same fuel cell, when fueled by hydrogen, achieved $60 \mathrm{~mW}$ at nominally 6 Volts. It charged a battery for a cellular phone. 


\section{ANALYTICAL MODELING OF CATHODE FLOODING}

Methanol crossover from the anode to the cathode results in poor fuel cell performance due to cathode catalyst poisoning. Lowering the crossover rate will slow down the rate of cathode poisoning, but unless the removal rate at the cathode (through evaporation and/or oxidation) is sufficiently fast, the fuel cell performance will still eventually degrade. For this reason, a model was designed to depict the cathode layer and to determine quantitative parameters that set, as a function of temperature and cathode flow rate, limits for transport and removal. From this model, we can determine the amount of methanol crossover that is permissible under certain operational conditions.

A finite difference model was written in QBasic. Solvent transport (methanol and/or water) from the anode to the cathode corresponds to proton transport, which is set by the current demand. Water generated directly at the cathode is also set by the cell current and voltage. The volume of available catalyst area at the cathode was calculated using the geometric cathode area, thickness of the active cathode layer, and catalyst porosity. The cathode is considered completely flooded when the volume of solvent at the cathode exceeds the void volume of the cathode layer. The volume of solvent at the cathode as a function of time was set by the rate of water generated at the cathode plus the solvent (water and methanol) delivered to the cathode across the membrane, minus the rate of solvent removal via evaporation and oxidation. Removal rate by evaporation is temperature and flow rate dependent.

The model accurately depicts that at high temperatures and cathode air flow rates, flooding is less of a problem because the methanol and water are being removed at a much higher rate. As the temperature decreases and the flow rate is reduced, much lower levels of crossover still cause flooding conditions at the cathode over time. Other investigators $^{22}$ operate DMFC at elevated temperature, regions where the natural processes of methanol vaporization and oxidation are far more rapid. At higher temperatures, because of these processes which tend to remove methanol from the electrocatalytic cathodic sites, higher conversion efficiency is measured. However, for devices designed to operate at room temperature, cathode poisoning remains a concern. This makes development of low temperature direct methanol fuel cells that do not use air compressors very challenging. Reductions in crossover are important, but systems should also be engineered to remove liquid buildup in some other manner (such as wicking, drainage, etc.) 


\section{CONCLUSION}

The goal of this research was to develop direct methanol fuel cells that use minute amounts of expensive catalysts, are easily mass produced, and are economically feasible. Evaluation and characterization of fuel cell components has led to the development of optimal materials for direct methanol fuel cell assemblies. The problem of methanol crossover has been reduced significantly. Low cost ionomer membranes have been

shown to operate effectively. Very thin barrier layers and catalysts with low loading levels were developed and tested. Operational fuel cell devices have been demonstrated. However, further improvements are needed to increase the power density at ambient operating conditions.

\section{ACKNOWLEDGEMENTS}

This work was supported by the Department of Energy CRADA \# LA97C10323. The assistance of Vincent Marciano with the diffusion and microscopy experiments was greatly appreciated.

\section{REFERENCES}

1. K. Scott, W. Taama, and J. Cruickshank, J. Appl. Electrochem., 28, 289-297 (1998).

2. A.K. Shukla, P.A. Christensen, A. Hamnett, and M.P. Hogarth, J. Power Sources, 55, 87-91 (1995), and references therein.

3. A.S. Arico, A. Poltarzewski, H. Kim, A. Morana, N. Giordano, and V. Antonucci, J. Power Sources, 55, 159-166 (1995).

4. K. Scott, W. Taama, and J. Cruickshank, J. Power Sources, 65, 159-171 (1997).

5. J. Cruickshank, and K. Scott, J. Power Sources, 70, 40-47 (1998).

6. J.S. Wainright, J.T. Wang, D. Weng, R.F. Savinell, and M. Litt, J. Electrochem. Soc., 142, L121-L123 (1995).

7. R. Wycisk, P..N. Pintauro, W. Wang, and S. O'Connor, J. Appl. Polym. Sci., 59, 1607-1617 (1996).

8. C. Pu, W. Huang, K. L. Ley, and E. S. Smotkin, J. Electrochem. Soc., 142, L119L120 (1995).

9. J. Haggin, Chem. \& Eng. News, 73, 8 (1995).

10. A.S. Arico, P. Creti, Z. Poltarzewski, R. Mantegna, H. Kim, N. Giordano, and V. Antonucci, Materials Chemistry and Physics, 47, 257-262 (1997).

11. Tri D. Tran and Stanley Langer, Anal. Chem. 65, 1805-1806 (1993). 
12. X.M. Ren, M.S. Wilson, and S. Gottesfeld, J. Electrochem. Soc., 143, L12-L15 (1996).

13. D.H. Jung, C.H. Lee, C.S. Kim, and D.R. Shin, J. Power Sources, 71, 169-173 (1998).

14. S. Cleghorn, P. Zelenay, X. Ren, and S. Gottesfeld, Abstracts of Papers of the Electrochemical Society, Inc., 98-1, 552, (May 3-8, 1998).

15. W.F. Lin, J.T. Wang, and R.F. Savinell, J. Electrochem. Soc., 144, 1917-1922 (1997).

16. S. Wasmus, J.T. Wang, and R.F. Savinell, J. Electrochem. Soc., 142, 3825-3833 (1995).

17. M. Hogarth, P. Christensen, A. Hamnett, and A. Shukla, J. Power Sources, 69, 125-136 (1997).

18. M. Hogarth, P. Christensen, A. Hamnett, and A. Shukla, J. Power Sources, 69 , 113-124 (1997).

19. M.K. Ravikumar and A.K. Shukla, J. Electrochem. Soc., 143, 2601-2606 (1996).

20. S. Surampudi, S.R. Narayanan, E. Vamos, H. Frank, G. Halpert, A. Laconti, J. Kosek, G.K.S. Prakash, and G.A. Olah, J. Power Sources, 47, 377-385 (1994).

21. S.J.C. Cleghorn, X. Ren, T.E. Springer, M.S. Wilson, C. Zawodzinski, T.A. Zawodzinski, and S. Gottesfeld, Int. J. Hydrogen Energy, 22, 1137-1144 (1997).

22. S.R. Narayanan, Fuel Cells for Transportation TOPTEC Meeting, Cambridge, MA., March 18-19 (1998). 


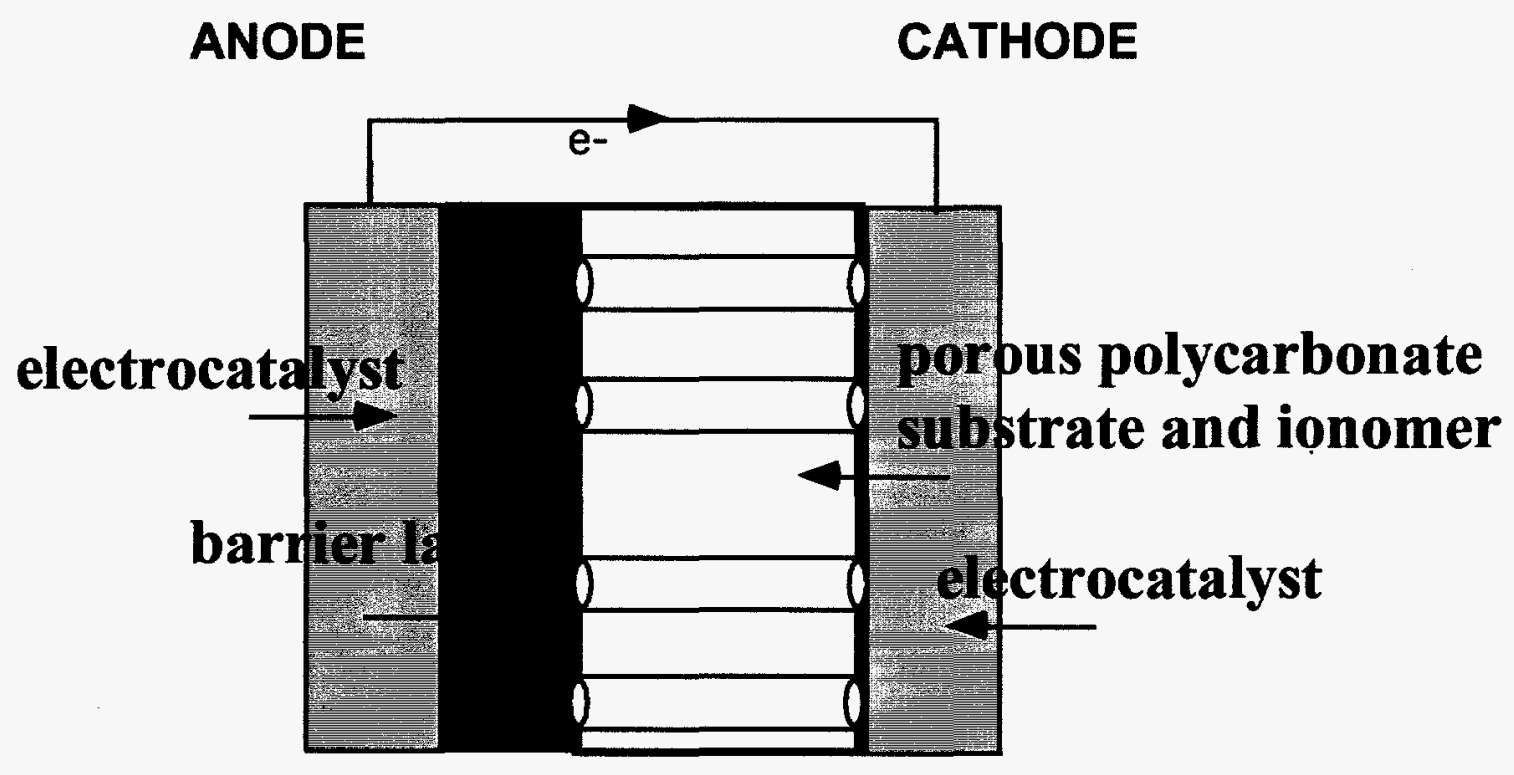

Figure 1. Schematic of the micro fuel cell.
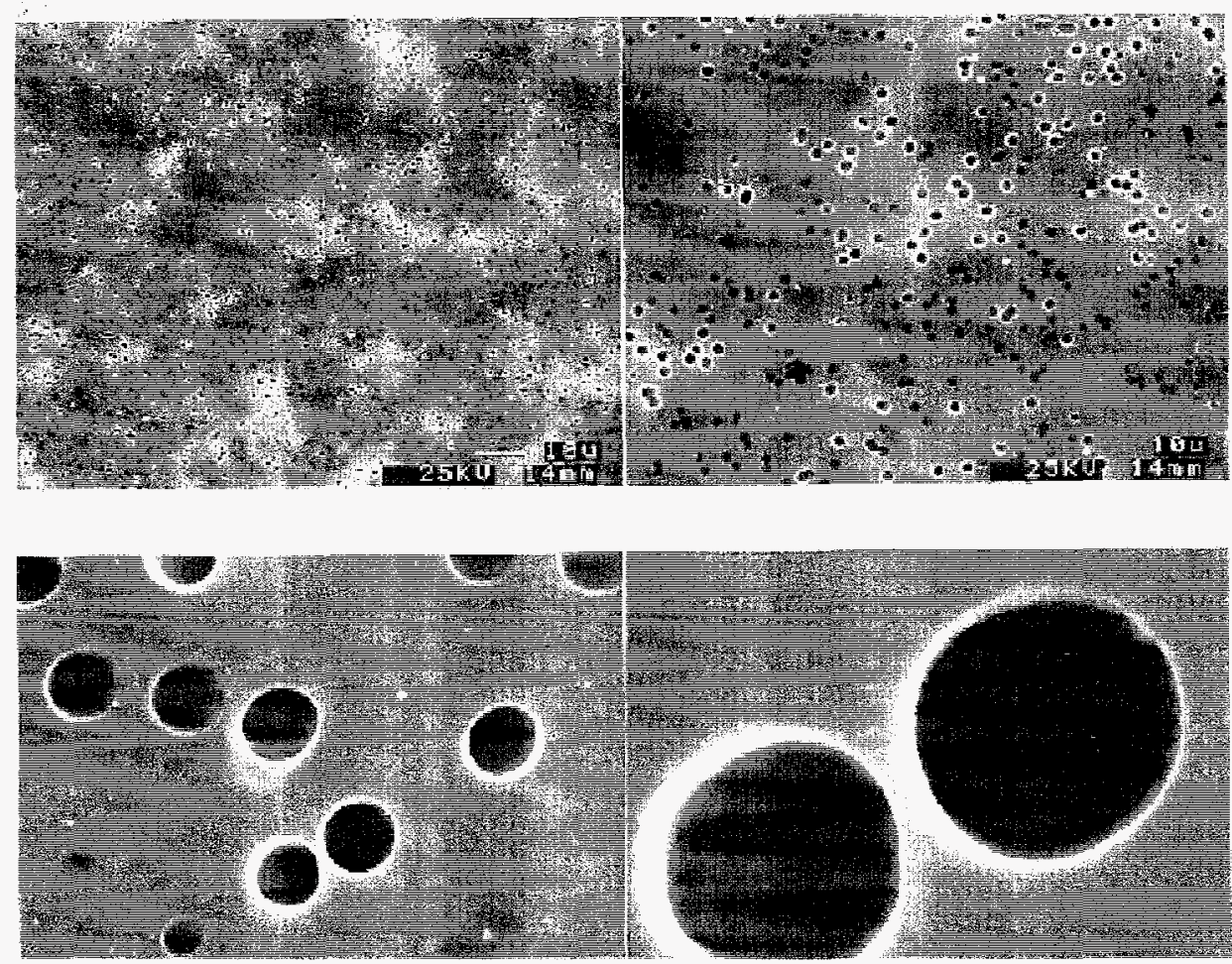

Figure 2. Polycarbonate membrane with heavy ion irradiated and etched pores. 


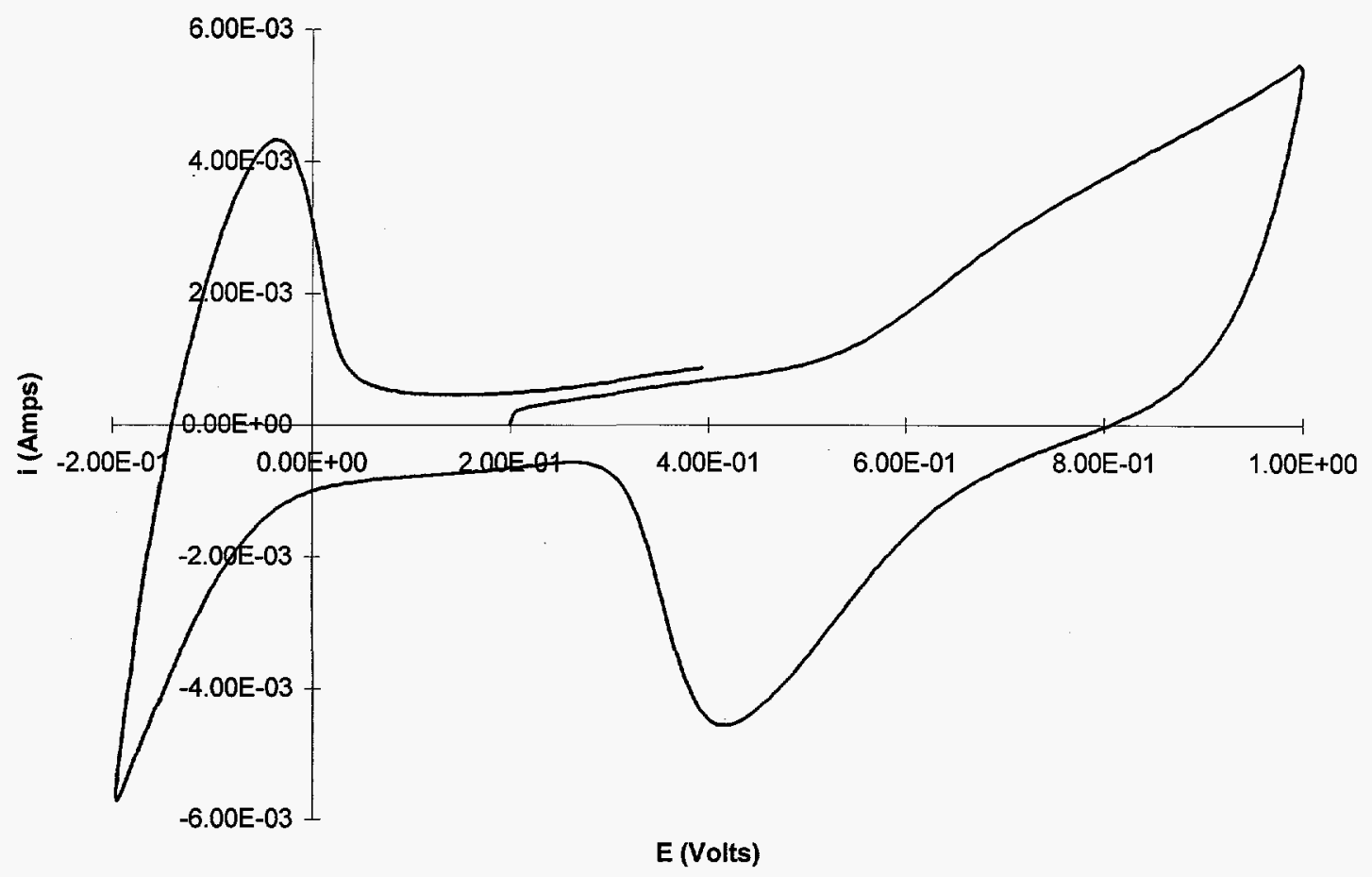

Figure 3. Representative cyclic voltammogram of catalyst film for surface area measurements.

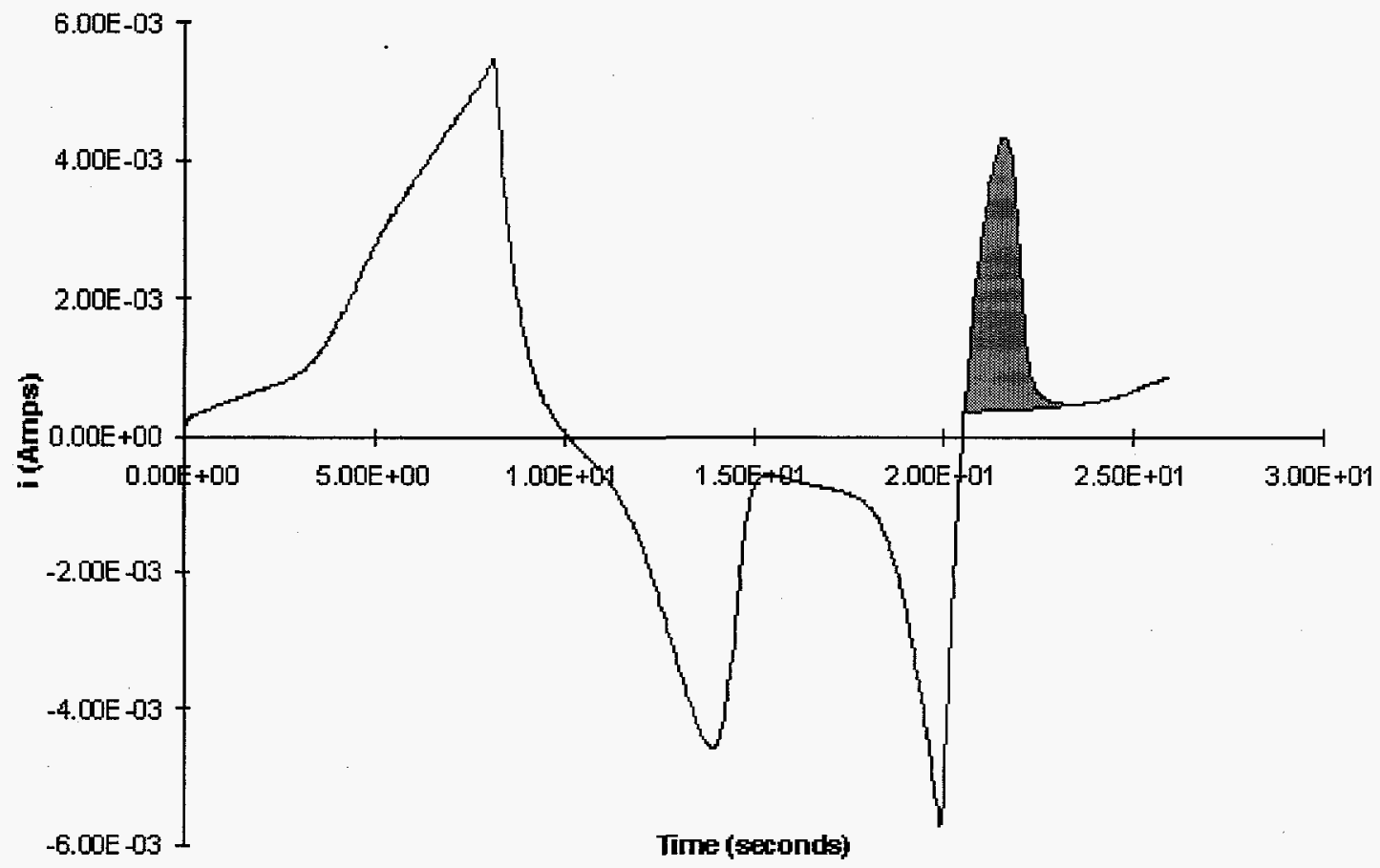

Figure 4. Coulometry of $\mathrm{H}_{2}$ desorption peak used to determine active catalyst area. 


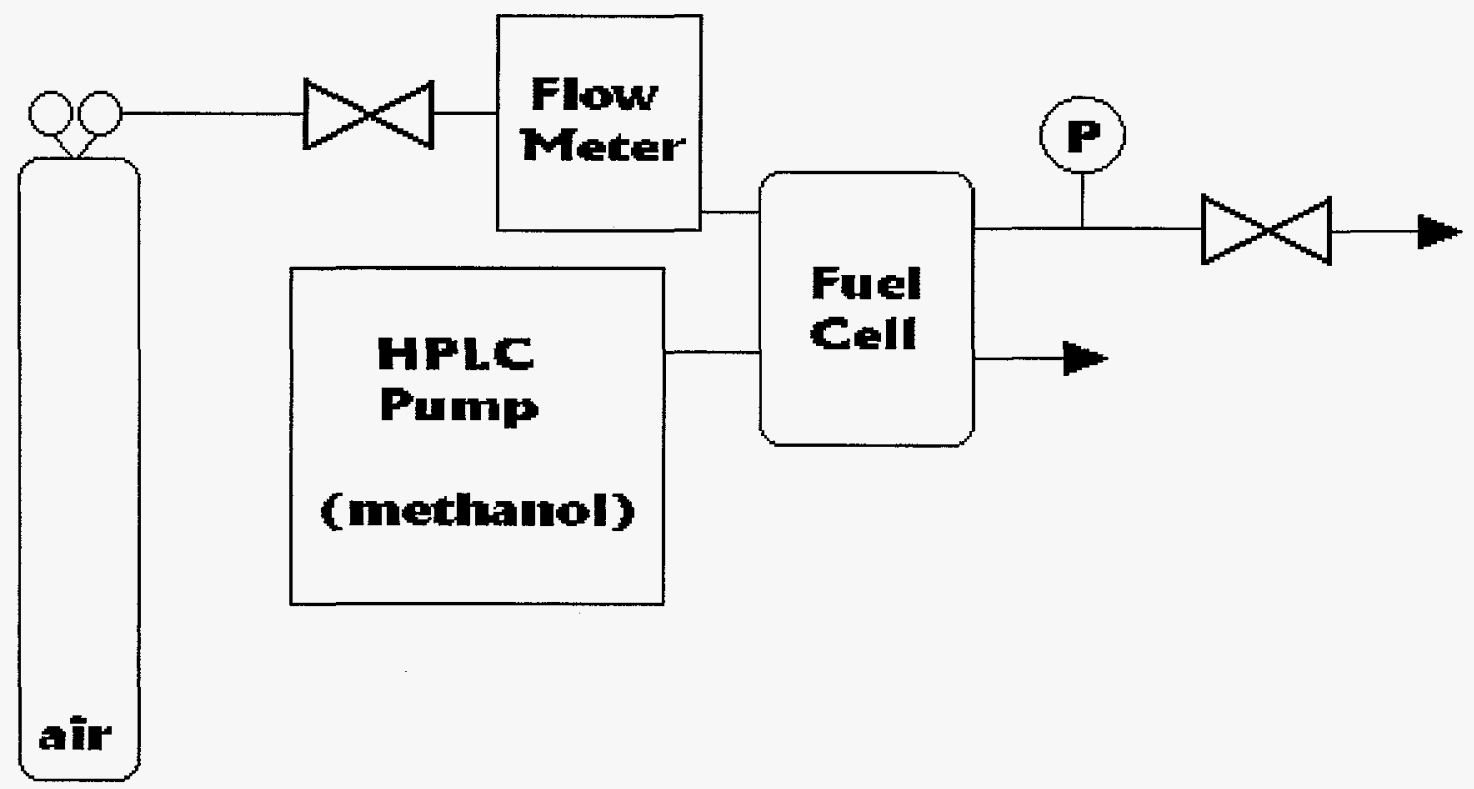

Figure 5. Single cell testing set-up.

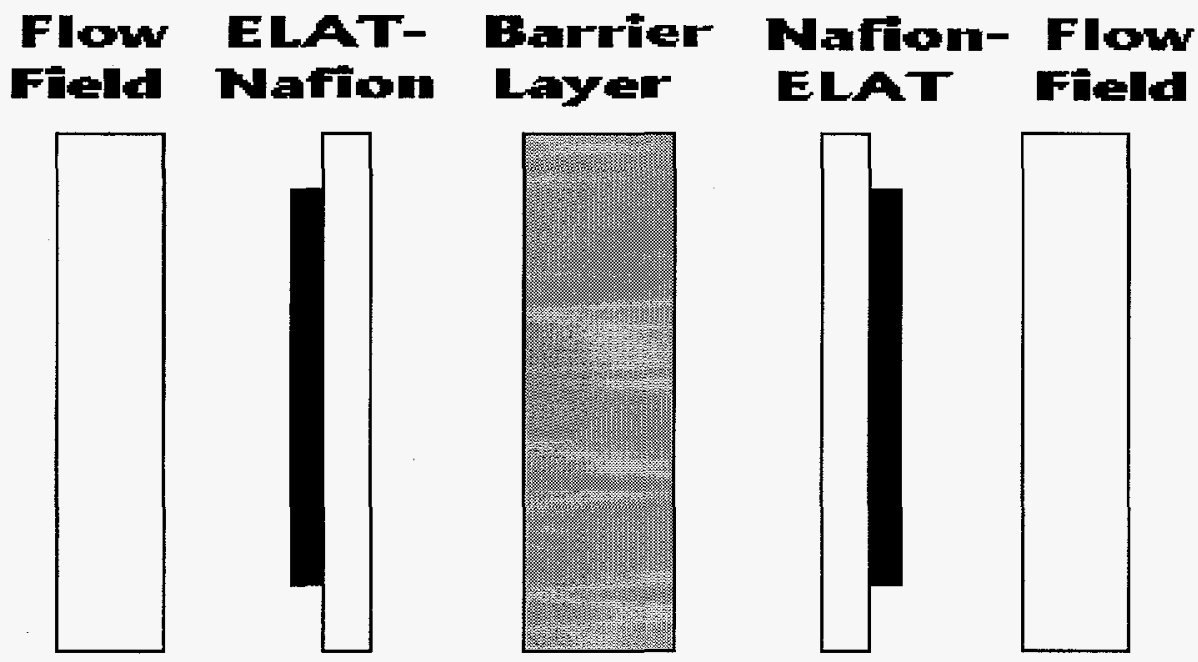

Figure 6. Fuel cell setup consisting of an MEA sandwiched between two graphite blocks with a barrier layer between two ELAT electrode/Nafion layers. 


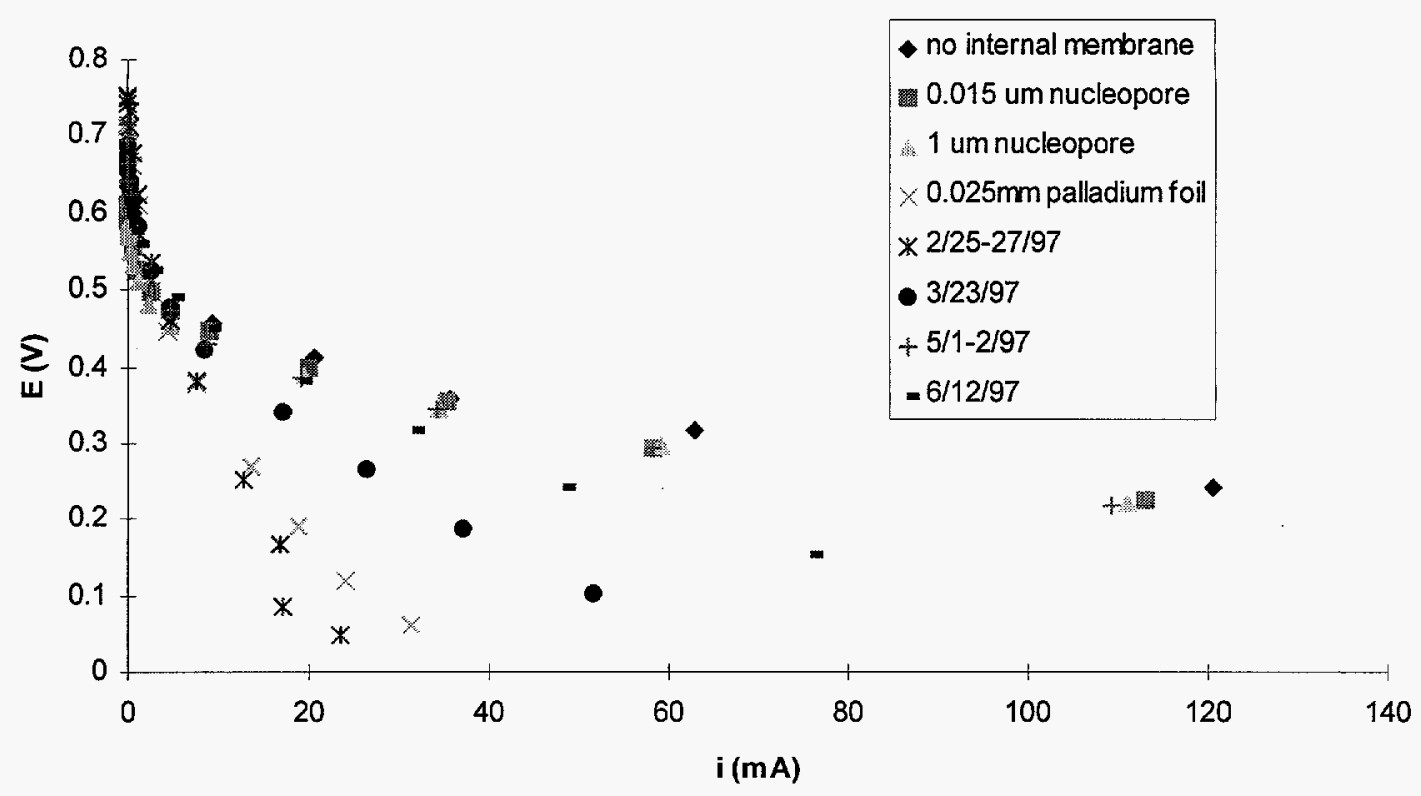

Figure 7. Polarization curves for MEA sandwiches using $1 \mathrm{M}$ methanol as the anode fuel and compressed air at the cathode.

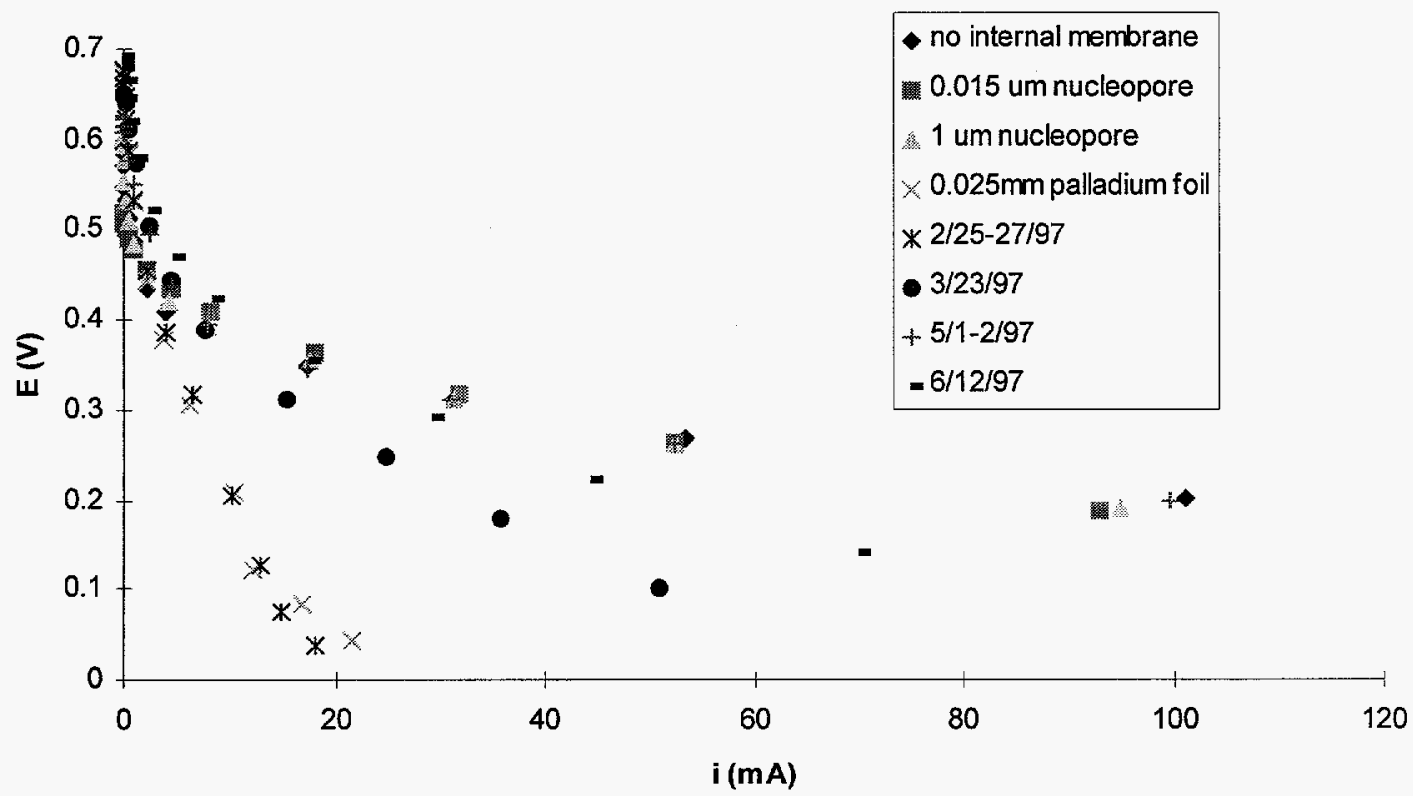

Figure 8. Polarization curves for MEA sandwiches using 3M methanol as the anode fuel and compressed air at the cathode. 


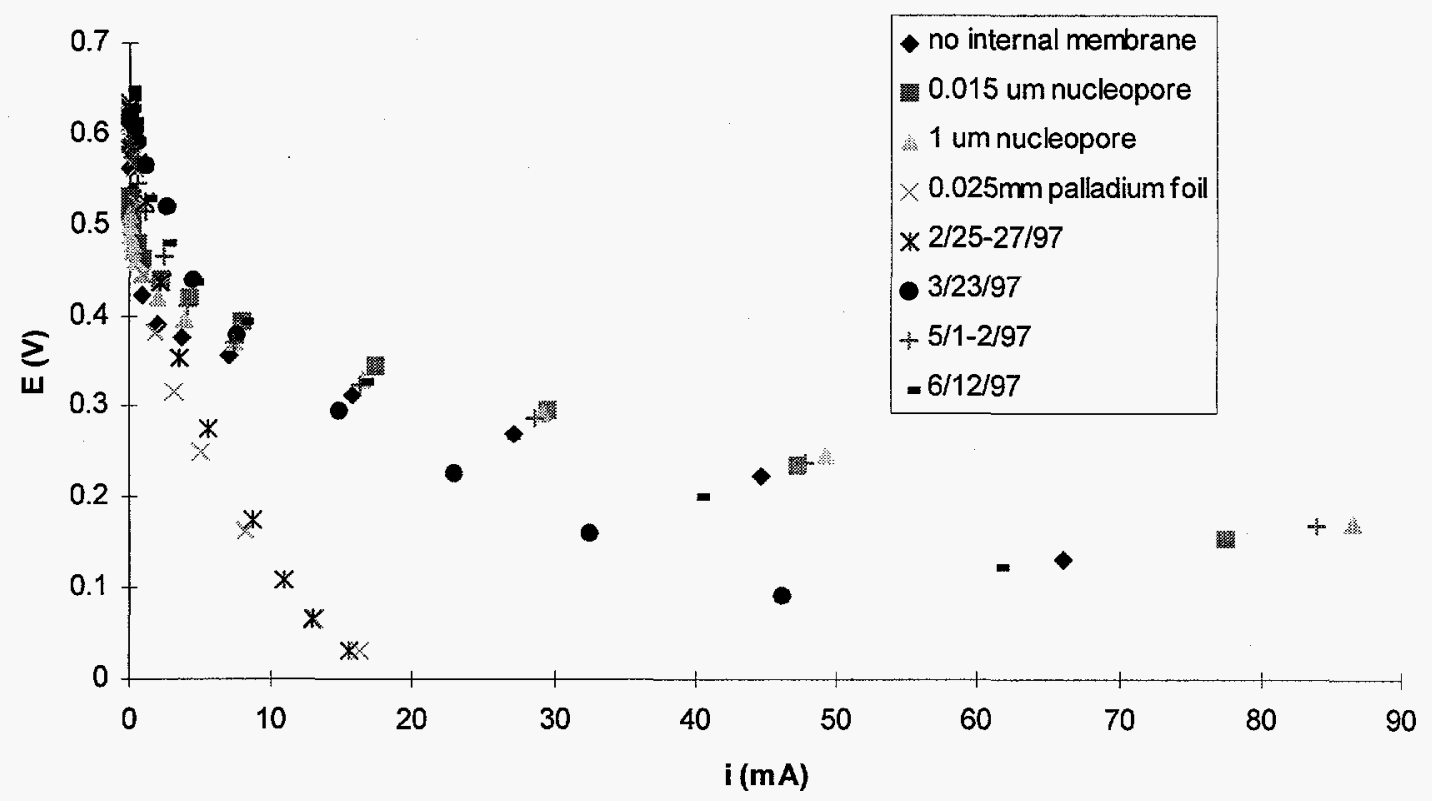

Figure 9. Polarization curves for MEA sandwiches using $8 \mathrm{M}$ methanol as the anode fuel and compressed air at the cathode.

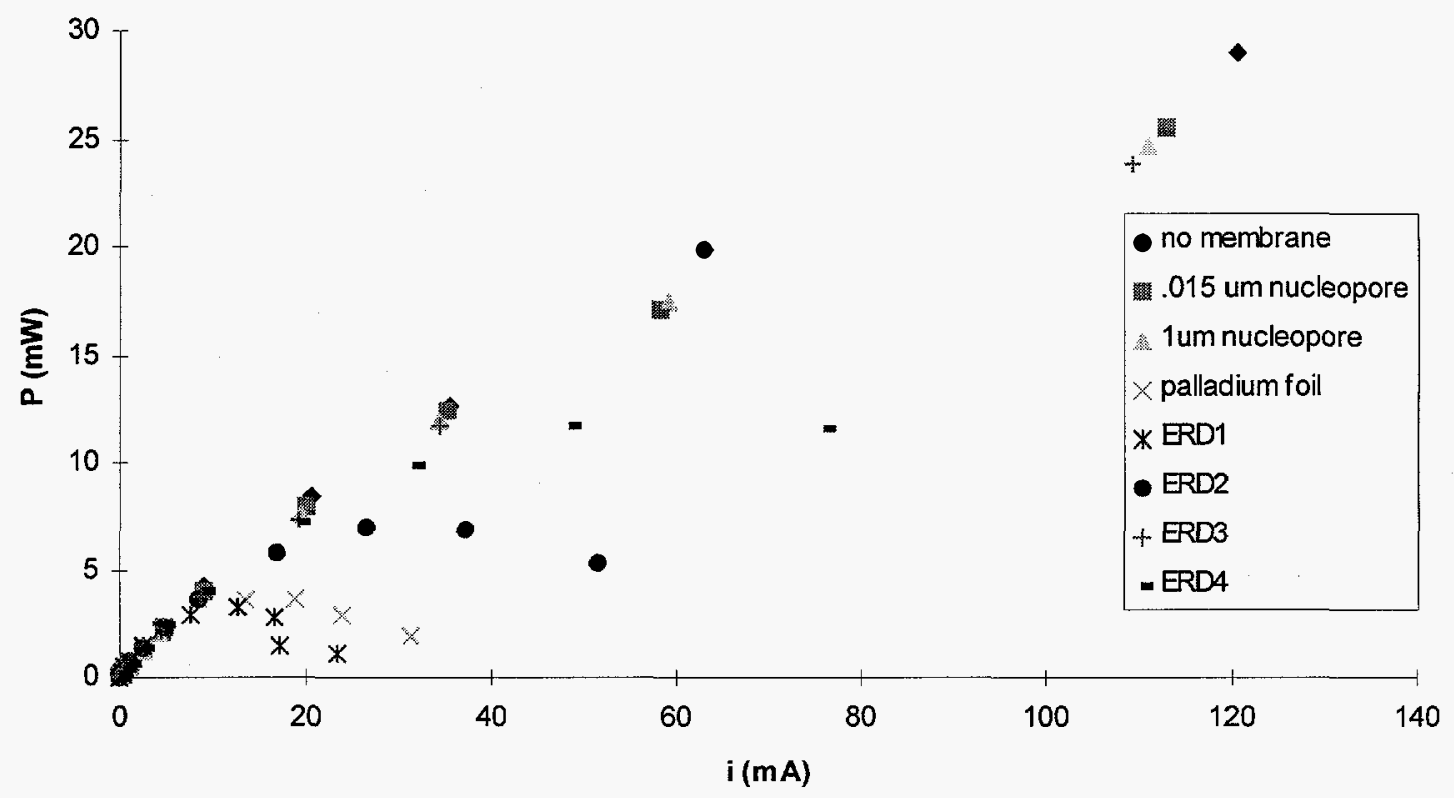

Figure 10. Power curves for MEA sandwiches with $1 \mathrm{M}$ methanol. 